\title{
Compound 32
}

National Cancer Institute

\section{Source}

National Cancer Institute. Compound 32. NCI Thesaurus. Code C1547.

A protein tyrosine kinase inhibitor that has specific activity for the epidermal growth factor receptor. $(\mathrm{NCl})$ 